\title{
Prolonged survival and immune reconstitution after chagasic meningoencephalitis in a patient with acquired immunodeficiency syndrome
}

\section{Sobrevida prolongada e reconstituição imunológica depois de meningoencefalite chagásica de um paciente com síndrome de imunodeficiência adquirida}

\author{
Marcelo Corti ${ }^{1}$ and Claudio Yampolsky ${ }^{2}$
}

\begin{abstract}
We report a case of cerebral meningoencephalitis due to Trypanosoma cruzi in a patient with acquired immunodeficiency syndrome. The patient presented with seizures and focal neurological signs. Definitive diagnosis of chagasic meningoencephalitis was made by demonstration of free trypomastigote forms in the cerebrospinal fluid. Benznidazol was prescribed with clinical and neurological improvement. Antiretroviral drugs improved cellular immunity and three years later the patient presents a good clinical condition with immune reconstitution and undetectable viral load. Chagasic meningoencephalitis has a poor prognosis when specific treatment is not initiated or is delayed. A high index of diagnosis is necessary for early diagnosis and treatment, especially in endemic areas for Trypanosoma cruzi infection.
\end{abstract}

Key-words: Chagas' disease. Trypanosoma cruzi. Meningoencephalitis. AIDS

\section{RESUMO}

Relatamos um caso de meningoencefalite devida ao Trypanosoma cruzi em um paciente com síndrome de imunodeficiência adquirida. o paciente apresentou convulsões e sinais neurológicos focais. O diagnóstico definitivo de meningoencefalite chagásica foi feito pela demonstração de formas tripomastigotas livres no líquor. Foi iniciado benznidazol com melhora clínica e neurológica. As drogas antiretrovirais melhoraram a imunidade celular e três anos mais tarde o paciente tinha uma boa condição clínica com reconstituição imunológica e carga viral indetectável. A meningoencefalite chagásica tem um prognóstico ruim quando o tratamento específico não é iniciado ou quando há demora para substituí-lo. É necessário um alto índice de suspeita para o diagnóstico e tratamento precoces, especialmente em áreas endêmicas para a infecção pelo Trypanosoma cruzi.

Palavras-chaves: Doença de Chagas. Trypanosoma cruzi. Meningoencefalite. SIDA.

Chagas' disease or American trypanosomiasis is an anthropozoonosis, endemic in Latin America and is caused by the flagellated protozoan Trypanosoma cruzi, transmitted to humans and animals by a family of haematophagus triatominae insects. Human beings may also acquire the infection by blood transfusions, transplacental route, infected transplanted organs or contaminated food ${ }^{2}$.
In Latin America, the disease affects about $25 \%$ of the population, with 16 to 18 million people infected and about 100 million at high risk of infection ${ }^{2}$.

The population with chronic infection is $7.2 \%^{2}$ in Argentina.

The progressive increase of Chagas' disease cases in urban populations as a result of massive migration from rural areas to major cities, associated with widespread infection caused

\footnotetext{
1. Division of HIV/AIDS Disease, F. J. Muñiz Infectious Diseases Hospital, Buenos Aires, Argentina. 2. Neurosurgery, F. J. Muñiz Infectious Diseases Hospital, Buenos Aires, Argentina.

Address to: Dr. Marcelo Corti. HIV/AIDS Division. Puán $3812^{\circ} \mathrm{C} 1406 \mathrm{CQG}$, Buenos Aires, Argentina.

Tel: $54114432-3762$

e-mail: marcelocorti@fibertel.com.ar

Recebido para publicação em 18/4/2005

Aceito em 24/11/2005
} 
by human immunodeficiency virus (HIV), have created the conditions for the emergence of a large number of coinfection cases ${ }^{1}$.

Chagas' disease can reactivate in patients with severe immunodeficiency associated with acquired immunodeficiency syndrome (AIDS) and generally presents with neurological compromise as brain mass lesions or acute diffuse meningoencephalitis (75-90\% of cases $)^{56}$. The central nervous system (CNS) tumor-like lesion is the most common manifestation; less frequently this reactivation may also present as episodes of a diffuse meningoencephalitis with trypomastigotes in the cerebrospinal fluid (CSF) ${ }^{21114}$.

We report a case of chagasic meningoencephalitis with focal brain lesions in a patient with AIDS who remains in good clinical condition three 3 years after diagnosis.

\section{CASE REPORT}

A 32-year-old man infected with the human immunodeficiency virus was admitted to our unit of AIDS-related opportunistic infectious diseases with fever, fatigue, headache and some seizure episodes. Physical examination revealed fever $\left(38^{\circ} \mathrm{C}\right)$, tachycardia (102 beats/min), hypotension $(100 /$ $60 \mathrm{mmHg}$ ) and weight loss of (approximately $10 \mathrm{~kg}$ in the three months prior to admittance). The patient also presented sensory compromise with obnubilation and a focal neurological syndrome consistent with hemiparesis with weakness of the face, arm and leg on the right side of the body. Lung auscultation was normal; the abdominal examination revealed hepatomegaly $(4 \mathrm{~cm}$ below the right costal margin); the spleen was not palpable.

Relevant laboratory findings were anemia with hematocrit $31 \%$, hemoglobin $9 \mathrm{~g} / \mathrm{uL}$, leucocytes $4,100 / \mathrm{mm}^{3}$ (76\% of PMN), platelet count $131,000 / \mathrm{mm}^{3}$ and CD 4 T cell count of 42 (4\%) cell/uL. The plasma viral load RNA-HIV was 71,188 copies/mL. Liver enzymes levels, coagulation tests and chest radiograph were normal. Blood, urine and sputum cultures for bacterial, mycobacterial and fungus were all negative. The anti-toxoplasma IgM was negative and $\operatorname{IgG}$ titer was positive $1 / 512$; serological assay for Trypanosoma cruzi (indirect immunofluorescence, passive hemagglutination and enzyme linked immunoassay) were reactive. The echocardiogram was normal.

A brain magnetic resonance imaging (MRI) showed a large right cortico-subcortical parieto-occipital lesion, hypointense in T1 weighted and hyperintense in T2 and FLAIR, with enhancement after the administration of gadolinium and surrounding edema, without mass effect rise the midline (Figure 1).

A presumptive clinical and radiological diagnosis of toxoplasma encephalitis was made and empirical antitoxoplasma treatment (pyrimethamine, clindamycin, leucovorin, dexamethasone and anticonvulsivants) was initiated.

After three weeks of empirical treatment the patient's neurological condition did not show any sign of recovery with a decrease in consciousness. A lumbar puncture was performed; the CSF profile was completely normal, with

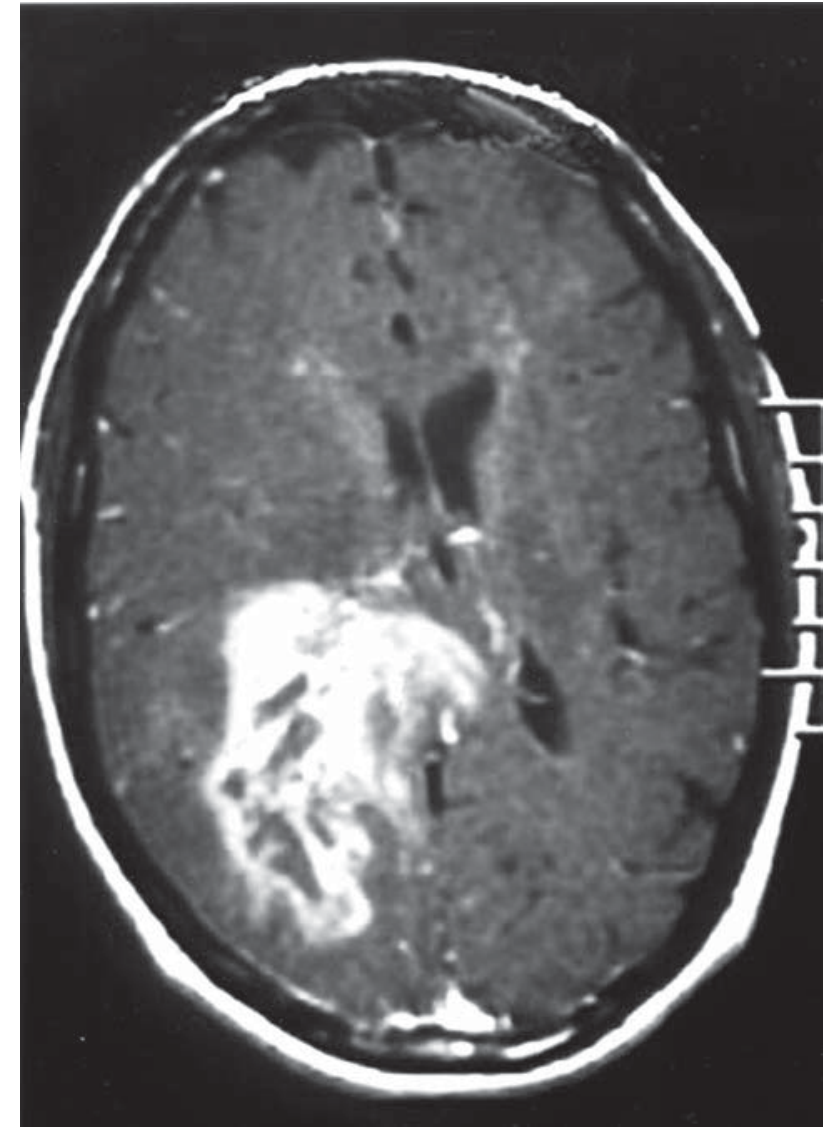

Figure 1 - Axial T1-weighted MRI showing a heterogenous right parietooccipital lesion with irregular gadolinium enhancement and perilesional edema, before treatment.

1 leukocyte, a glucose level of $52 \mathrm{mg} / \mathrm{dL}$ and a protein level of $32 \mathrm{mg} / \mathrm{dL}$. The results of bacterial, mycobacterial and fungus cultures were negative. Cryptococcal antigenemia was negative. PCR for JC virus and herpes neurovirus (EpsteinBarr virus, cytomegalovirus, varicella-zoster and herpes simplex virus) and VDRL in CSF were all negative. CSF smears with Giemsa stain demonstrated abundant free motile and flagellated trypomastigote forms of the protozoan Trypanosoma cruzi. Three buffy-coat smears were negative for parasitemia detection.

The patient was treated with the specific antitrypanosomal drug benznidazol at a dose of $5 \mathrm{mg} / \mathrm{kg} /$ day twice daily, for 60 days with good clinical and neurological response. After, he received a secondary prophylaxis based on benznidazol at a dose of $200 \mathrm{mg}$ three times a week, and antiretroviral therapy based on zidovudine plus lamivudine plus efavirenz was initiated. Three years after the onset of neurological symptoms he remains in good clinical condition; the secondary prophylaxis was interrupted, the CD4 T cell count is $>250$ cell/uL and the plasma RNA-HIV viral load is undetectable.

The last MRI scan of the brain demonstrated a right sequelar atrophic cortico-subcortical parieto-occipital image, with partial cavitation, hypointense in T1, hyperintense in $\mathrm{T} 2$ and hypointense in FLAIR, consistent with gliosis. This lesion is associated with retraction of the brain ventricular system (Figure 2). 


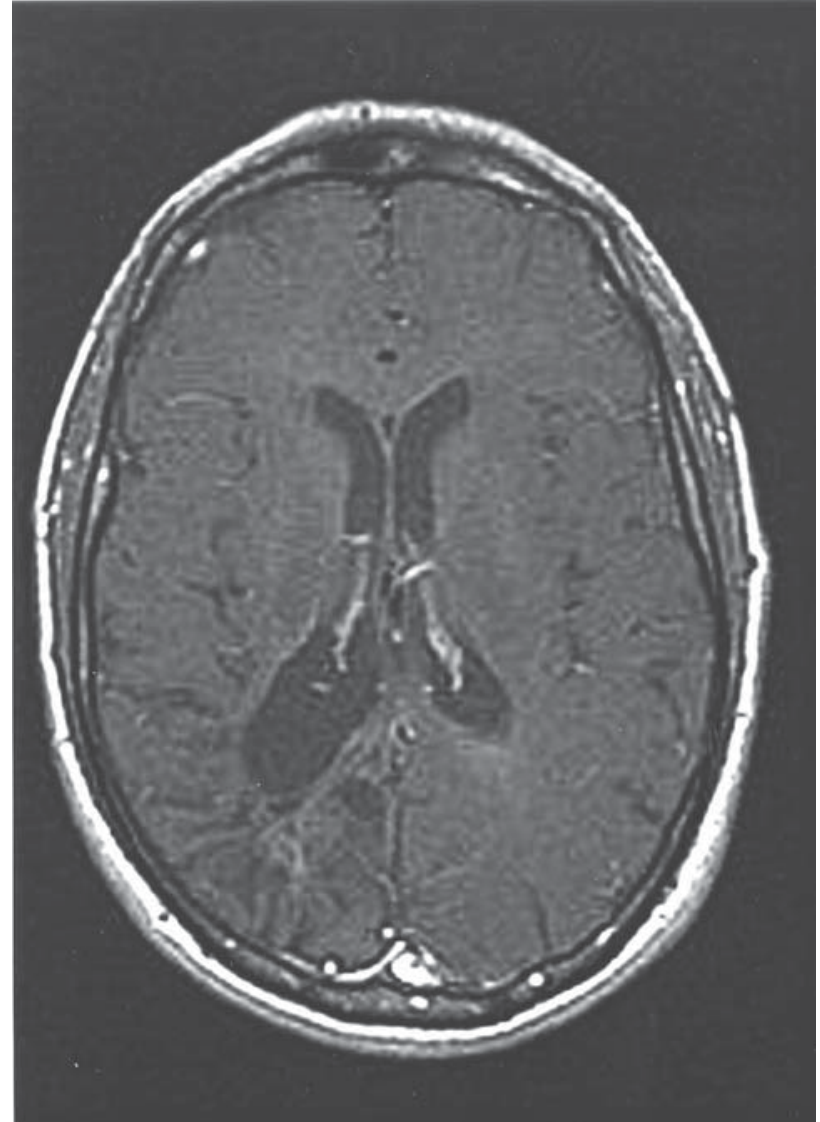

Figure 2 - Axial T1-weighted of the last MRI scan obtained three years after the diagnosis reveals a sequelar lesion with partial cavitation, the degree of enhancement and brain retraction.

\section{DISCUSSION}

Neurological involvement in patients with AIDS is common. Approximately $40 \%$ to $60 \%$ of patients with AIDS develop some neurological disorder at some stage of the disease ${ }^{4}$. Acute exacerbation of chronic Chagas' disease can occur in immunocompromised patients, especially in individuals with the involvement of cellular immunity. In this context, patients with advanced HIV/AIDS disease can develop an acute diffuse meningoencephalitis or an intracranial mass lesion caused by Trypanosoma cruzi. Neuroimages including MRI and computerized tomography generally show single or multiple lesions with a hypodense or hypointense center, with or without contrast-enhancement and with or without mass effect, indistinguishable from that of Toxoplasma gondii encephalitis. The imaging pattern of brain chagoma is similar to that cerebral toxoplasmosis ${ }^{8113}$. Although primary central nervous system lymphoma and toxoplasma encephalitis continue to be the most common intracranial lesions in HIV-infected patients, other causes of cerebral mass lesions, such as tuberculosis, cryptococcosis, nocardiosis and Chagas' disease, should be considered in the differential diagnosis of enhancing lesions of the central nervous system in patients with $\operatorname{AIDS}^{47}$.

In endemic areas for $T$. cruzi infection, all HIV patients presenting with cerebral brain lesions should be evaluated for specific anti-T.cruzi antibodies and for parasitemia ${ }^{1}$.
The detection of parasitemia using the gross drop method to identify trypomastigotes are more frequent in HIV seropositive patients in comparison with seronegative people ${ }^{1516}$. Sartori el al ${ }^{17}$ emphasized the importance of routine detection of parasitemia in the reactivation of Chagas' disease in immunocompromised patients. The CSF profile may be normal, as in our patient, or can be associated with lymphocyte pleocytosis and hyperproteinorraquia. Also, CSF samples from AIDS patients with diffuse meningoencephalitis should be routinely sent to the parasitology laboratory for the detection of trypomastigotes, as was seen in our patient ${ }^{10}$. Centrifugation of the CSF enhances the sensibility of this test ${ }^{6}$.

When $T$. cruzi trypomastigotes cannot be demonstrated in the CSF, a cerebral biopsy of focal brain lesions may be necessary. Histopathological findings include focal necrotizing encephalitis with amastigotes of $T$. cruzi in Giemsa smears ${ }^{9}$.

Additionally, concomitant cardiac involvement with acute myocarditis suggests the possibility of the reactivation of Chagas' disease. Myocarditis is the second most frequent variation of Chagas' disease reactivation in patients with $\operatorname{AIDS}^{1617}$.

Fatal outcome is high in reported cases of AIDS associated chagasic meningoencephalitis ${ }^{3}$. Ferreira MS at $\mathrm{al}^{7}$ reported a short median survival (10 days) for these patients ${ }^{7}$. Sinagra and colleagues ${ }^{18}$ reported eight patients who died during benznidazol therapy and two other patients who died six to eight months after the reactivation of the disease.

In conclusion, Chagas' disease must be considered in the differential diagnosis of meningoencephalitis, with or without focal brain lesions, in AIDS patients. Sometimes, reactivation of Trypanosoma cruzi infection is the first AIDS - defining disease. A correct diagnosis based on epidemiological, clinical and serological information has a significant impact on patient survival. A poor outcome is related with a delay in establishing the correct diagnosis ${ }^{12}$.

The potential impact of highly active antiretroviral therapy (HAART) and immune reconstitution in reactivation of Chagas' disease associated with AIDS remains to be established. Early diagnosis followed by specific therapy with benznidazol or nifurtimox and immune reconstitution associated with HAART should improve the survival rate of these patients, such as the case described. Long term secondary prophylaxis with benznidazol is necessary until the immune reconstitution associated with HAART.

\section{REFERENCES}

1. Brito AM, Castilho EA, Szwarcwald CL. AIDS e infecção pelo HIV no Brasil: uma epidemia multifacetada. Revista da Sociedade Brasileira de Medicina Tropical 34:207-217, 2001.

2. Corti M. AIDS and Chagas' disease. Aids Patient Care and STDs 14: 581$588,2000$.

3. Corti M, Trione N, Corbera K, Vivas C. Chagas' disease: another cause of cerebral mass occurring in patients with acquired immunodeficiency syndrome. Enfermedades Infecciosas y Microbiología Clínica 18: 194-196, 2000 . 
4. Corti M, Yampolsky C, Metta H, Valerga M, Sevlever G, Capizzano A. Oligodendroglioma in a patient with AIDS: case report and review of the literature. Revista do Instituto de Medicina Tropical de São Paulo 46: 195$197,2004$.

5. Ferreira MS. A síndrome da imunodeficiencia adquirida e as doenças endêmicas no Brasil. Revista da Sociedade Brasileira de Medicina Tropical 29:531-535, 1996

6. Ferreira MS, Borges AS. Some aspects of protozoan infections in immunocompromised patients: a review. Memórias Instituto Oswaldo Cruz 97:443-457, 2002

7. Ferreira MS, Nishioka SA, Silvestre MT, Borges As, Nunes-Araujo FR, Rocha A. Reactivation of Chagas' disease in patient with AIDS: report of three new cases and review of the literature. Clinical Infectious Diseases 25: 1397-1400, 1997.

8. Hoff R, Texeira RS, Carvalho JS, Mott KE. Trypanosoma cruzi in the cerebrospinal fluid during the acute stage of Chagas' disease. New England Journal of Medicine 298:604-606, 1978

9. Karp CL, Neva FA. Tropical infectious diseases in Human Immunodeficiency virus-infected patients. Clinical Infectious Diseases 28:947-965, 1999.

10. Lazo J, Meneses AC, Rocha A, Ferreira MS, Marquez JO,Chapadeiro E, Lopes ER. Chagasic meningoencephalitis in the immunodeficient. Arquives de Neuropsiquiatria 56:93-97, 1998

11. Livramento JA, Machado LR, Spina-França A. Cerebrospinal fluid abnormalities in 170 cases of AIDS. Arquives de Neuropsiquiatria 47:326331, 1989.

12. Madalosso G, Pellini ACG, Vasconcelos MJ, Ribeiro AF, Weissmann L, Oliveira Filho GS, Oliveira ACP, Vidal JE. Chagasic meningoencephalitis: case report of a recently included AIDS-defining illness in Brazil. Revista do Instituto de Medicina Tropical de São Paulo 46:199-202, 2004.

13. Montero A, Cohen JE, Martinez DP, Giovannoni AG. Tratamiento empírico anti-toxoplasma en SIDA y Chagas cerebral: relato de dos casos, revisión de la bibliografía y propuesta de un algoritmo. Medicina (Buenos Aires) 58:504-506, 1998

14. Pagano MA, Segura MJ, Di Lorenzo GA, Garau ML, Molina HA, Cahn P, Perez H, Vitolo F, Grondona A, Piedimonte FC, Giannaula R, Ramia R, Miranda MA, Sierra H, Sica RE. Cerebral tumor-like American trypanosomiasis in acquired immunodeficiency síndrome. Annals of Neurology 45: 403-406, 1999.

15. Sartori AM, E Neto J, Nunes EV, Braz LM, Caiaffa-Filho HH, Oliveira Jr OC, Amato Neto V, Shikanai-Yasuda MA. Trypanosoma cruzi parasitemia in chronic Chagas' disease: comparison between human immunodeficiency virus (HIV)-positive and HIV-negative patients. Journal of Infectious Diseases 186:872-875, 2002

16. Sartori AM, Lopes MH, Benvenuti LA, Caramelli B, di Pietro A, Nunes EV, Ramirez LP, Shikanai-Yasuda MA. Reactivation of Chagas' disease in a human immunodeficiency virus-infected patient leading to severe heart disease with a late positive direct microscopic examination of the blood. The American Journal of Tropical Medicine and Hygiene 59:784-786, 1998.

17. Sartori AM, Lopes MH, Caramelli B, Duarte MI, Pinto PL, Amato Neto V, Shikanai-Yasuda MA. Simultaneous occurrence of acute myocarditis and reactivated Chagas' disease in a patient with AIDS. Clinical Infectious Diseases 21:1297-1299, 1995.

18. Sinagra A, Luna C, Iriarte A. AIDS and Chagas' disease. Medicina (Buenos Aires) 59(suppl III):22-23, 1999 